\title{
Dan Wylie and Craig MacKenzie, eds. "No Other World": Essays on the Life-Work of Don Maclennan
}

Noordhoek: Print Matters Heritage, 2012. 264 p. ISBN 9780987009524. US $\$ 41.74$

\section{Fiona McCann}

\section{(2) OpenEdition}

\section{Journals}

Electronic version

URL: https://journals.openedition.org/ces/410

DOI: $10.4000 /$ ces. 410

ISSN: 2534-6695

\section{Publisher}

SEPC (Société d'études des pays du Commonwealth)

\section{Printed version}

Date of publication: 30 November 2018

Number of pages: 153-154

ISSN: 2270-0633

\section{Electronic reference}

Fiona McCann, "Dan Wylie and Craig MacKenzie, eds. "No Other World": Essays on the Life-Work of Don Maclennan", Commonwealth Essays and Studies [Online], 41.1 | 2018, Online since 05 November 2019, connection on 23 August 2021. URL: http://journals.openedition.org/ces/410 ; DOI: https://doi.org/ $10.4000 /$ ces. 410

\section{(c) (i) (9)}

Commonwealth Essays and Studies is licensed under a Licence Creative Commons Attribution - Pas d'Utilisation Commerciale - Pas de Modification 4.0 International. 
"No Other World": Essays on the Life-Work of Don Maclennan. Edited by Dan Wylie and Craig MacKenzie. Noordhoek: Print Matters Heritage, 2012. 264 p. ISBN: 978-09870-095-24. US\$41.74

Reviewed by Fiona McCANN

This collection brings together intimate reflections and academic articles on a lesser-known and, the contributors argue, to date underrated South African academic, playwright, fiction writer, and poet, Don Maclennan (1929-2009). Born in England, Maclennan moved to South Africa when he was still a boy, and although he subsequently studied for a short while at Edinburgh University, and lived and taught for a couple of years in the United States, his home became South Africa. He held temporary lectureship posts at both the University of Witswatersrand and the University of Cape Town before finally taking up a post at Rhodes University in 1966, where he taught until well after he officially retired in 1994. Right up until his death from Motor Neuron Disease in 2009, Don Maclennan continued to produce new poetry, publishing ten books between 1971 and 1998, thirteen collections from 2001 on, and his final collection, Dress Rehearsal, was published posthumously in 2010. Some of these works were self-published, while others were published by various South African poetry presses, but there is no doubting the prolific output of this poet.

As Craig MacKenzie points out in his article, Maclennan "cannot be made to stand for any single idea, literary movement, or ideological position" (95), and the protean nature of his work is very much reflected in this homage to him. "No Other World" is divided into four different parts which reflect the multiple approaches to Maclennan's life and work and the editors' evident wish to reconcile a homage to the intimate friendships the poet developed over a lifetime, as well as his influence on younger poets and scholars, with a more academic appraisal of his work, in particular his poetry. While Part One consists of a piece by Maclennan's wife, Shirley, and an interview with Maclennan himself, Part two contains a series of moving tributes to the man, the playwright, and the poet. These first two parts devote particular attention to love and friendship and, perhaps inevitably, do not entirely avoid the pitfall of, as Harry Owen puts it in his piece, "beginning to sound disturbingly devotional" (42). These contributions sketch a picture of the multiple roles fulfilled by Maclennan during his lifetime, as a husband and father (Shirley Maclennan), as a friend (John Forbis), as a mentor for younger, aspiring poets (Harry Owen), as an amateur climber (Gavin Stewart), and as an actor and playwright who collaborated with Athol Fugard (André Lemmer and Peter Vale). Given the political tensions of the period, one might regret, however, that in these more personal pieces there is so little mention of any development or expression of modes of resistance to apartheid.

Part three is the longest and most "academic" part of the collection, proposing eight articles which engage critically with Maclennan's non-academic publications. Craig MacKenzie contextualizes "the (non-) reception" of Maclennan's poetry (89), painstakingly showing how various important poetry anthologies ranging from Stephen Gray's 1976 A World of Their Own: Southern African Poets of the Seventies to Michael Chapman's 2002 A New Century of South African Poetry have in some cases completely ignored it, and in others simply underrepresented it. Malvern van Wyk Smith provides an interes- 
ting overview of themes and moods in Maclennan's poetry, while Christine Lucia and Michael Blake present a fascinating exploration of the interplay between the poet's work and music, weaving critical analysis with concrete examples of collaborations resulting in intermediality. It is in this article that there is perhaps the most sustained engagement with the form and aesthetics of Maclennan's poetry and the difficulty of displacing these when putting the poetry to music. Laurence Wright analyzes the rather opaque Notes from a Rhenish Mission suggesting that it represents "history as metaphor" (151), and in a close reading of the poem, reveals its "metaphysical-poetic programme" (156). Mariss Everitt investigates Maclennan's 2003 Letter to William Blake and traces the influences of both Blake and Dante as well as the tension between spirituality and reason in the South African poet's work where his "preoccupation with death" looms large (183). Nimi Hoffmann presents an analysis of the difficulties of translating Maclennan's poetry, particularly The Necessary Salt (2006), into German, while Brendon Robinson, author of an MA thesis on Maclennan's poetry observes and explains the ways in which the poet's engagement with Western philosophy emerges in his work. The final essay in this section, by Dan Wylie, explores the presence of a "fascination with the prehistoric or precolonial cultures" of South Africa in Maclennan's prose and poetry (219), and is one of the more original contributions to this unusual collection.

Part four consists of a very useful detailed bibliography of Maclennan's works, compiled in conjunction with the National English Literary Museum in Grahamstown, and ends with a call for further study of Maclennan's work. For anyone wishing to heed this call, "No Other World" will now be a mandatory point of departure. As a whole, the collection has tried to balance a homage to a charismatic university teacher and friend with a more academic approach to his poetic work, and at times the emphasis is perhaps placed too much on the man and not enough on the actual poetry as aesthetic acts. However, although it generally concentrates much more on unpacking the many layers of meaning in Maclennan's poetry than on its actual stylistics, it provides interesting insight into the writer himself, his interests, and his major preoccupations and as such, will be of interest to scholars working on South African poetry generally and this poet in particular. 